IZA DP No. 5479

The Effect of Immigration on the School

Performance of Natives: Cross Country Evidence Using PISA Test Scores

Giorgio Brunello

Lorenzo Rocco

February 2011 


\title{
The Effect of Immigration on the School Performance of Natives: Cross Country Evidence Using PISA Test Scores
}

\author{
Giorgio Brunello \\ University of Padova, \\ CESifo and IZA \\ Lorenzo Rocco \\ University of Padova
Discussion Paper No. 5479
February 2011 \\ IZA \\ P.O. Box 7240 \\ 53072 Bonn \\ Germany \\ Phone: +49-228-3894-0 \\ Fax: +49-228-3894-180 \\ E-mail: iza@iza.org
}

Any opinions expressed here are those of the author(s) and not those of IZA. Research published in this series may include views on policy, but the institute itself takes no institutional policy positions.

The Institute for the Study of Labor (IZA) in Bonn is a local and virtual international research center and a place of communication between science, politics and business. IZA is an independent nonprofit organization supported by Deutsche Post Foundation. The center is associated with the University of Bonn and offers a stimulating research environment through its international network, workshops and conferences, data service, project support, research visits and doctoral program. IZA engages in (i) original and internationally competitive research in all fields of labor economics, (ii) development of policy concepts, and (iii) dissemination of research results and concepts to the interested public.

IZA Discussion Papers often represent preliminary work and are circulated to encourage discussion. Citation of such a paper should account for its provisional character. A revised version may be available directly from the author. 
IZA Discussion Paper No. 5479

February 2011

\begin{abstract}

\section{The Effect of Immigration on the School Performance of Natives: Cross Country Evidence Using PISA Test Scores*}

We study whether a higher share of immigrant pupils affects the school performance of natives using aggregate multi-country data from PISA. We find evidence of a negative and statistically significant relationship. The size of the estimated effect is small: doubling the share of immigrant pupils in secondary schools from its current sample average of 4.8 percent to close to 10 percent would reduce the test score of natives by 1.32 to 1.96 percent, depending on the selected group of natives. There is also evidence that - conditional on the average share of immigrant pupils - reducing the dispersion of this share between schools has small positive effects on the test scores of natives.
\end{abstract}

JEL Classification: J15, I28

Keywords: immigrants, school performance, natives

Corresponding author:

Giorgio Brunello

Department of Economics

University of Padova

Via del Santo 33

35100 Padova

Italy

E-mail: giorgio.brunello@unipd.it

\footnotetext{
* We are grateful to Erich Battistin and Alessandra Venturini and to the audience at the first CSEA seminar in Padova for comments and suggestions. A previous version of this paper appeared as CSEA working paper (www.decon.unipd.it/index.php? $p=$ project01). Financial support from Centro Studi Economici Antonveneta is gratefully acknowledged. The usual disclaimer applies.
} 


\section{Introduction}

Immigration flows have changed the composition of students in schools and classes. The integration of immigrants is often problematic, and these flows have triggered in some countries the flight of natives from public to private schools. A key question is whether the increased share of immigrants in schools and classes has affected the school performance of natives. In spite of the importance of this question for education policy, and of the abundance of research investigating the labour market effects of immigrants, relatively little is known about the impact of immigration on the education system (see Gould, Lavy and Paserman, 2009).

To our knowledge, this paper is the first to address this important question using cross - country data covering European and Anglo-Saxon countries. Measuring the effect of immigrants on the school performance of natives is complicated by the fact that immigrants sort across countries and both immigrant and native students self-select into schools and classes. For example, the share of immigrants in the total population is typically higher in more developed countries, where economic opportunities are more abundant. At the same time, students in these countries tend to have a better performance, because their schooling systems are more effective. Therefore, the average test scores of native students and the share of immigrants tend to be positively correlated across countries, but this correlation is spurious and driven by cross-country differences in economic development.

Due to economic conditions, immigrants usually concentrate in less affluent neighbourhoods, where housing prices are lower. Typically, the schools of these neighbourhoods are attended both by immigrant students with limited language proficiency and by native students with a relatively poor parental background. By virtue of this sorting, a negative correlation between the test scores of natives and the share of immigrants in the school is likely to emerge within each country quite independently of whether immigrants have or have not any impact on the school performance of native students. Non random allocation of students to schools implies that it is difficult to tell whether the correlation between the performance of natives and the share of immigrants in a school can be treated as a causal relationship. 
In this paper, we address sorting within countries by aggregating at the country level the key information on the test scores of natives and the shares of immigrant students. By virtue of aggregation, we remove the sorting of individuals across schools ${ }^{1}$. However, immigrants can sort also among different countries. Using data that vary by country and time, we control for between - country migration flows by conditioning on country fixed effects and on the stock of immigrants in a given country at a given time. Conditional on this stock, the share of immigrant pupils in each country depends mainly on demographic factors and is as good as random, as pointed out by Gould, Lavy and Paserman, 2009, in their study of the effects of immigration in Israel schools.

We find that a higher share of immigrant pupils reduces the school performance of 15-years old natives. The marginal effect, however, is small and varies with the gender and the parental background of natives. Our evidence suggests that doubling the share of immigrant students from the current average 5 percent to 10 percent $^{2}$ would reduce the average school performance of natives by 1.32 to 1.96 percent. The highest negative effect is found for natives with relatively poor parental background, who typically concentrate in schools with a high proportion of immigrants.

We also find that the estimated effect of immigrant pupils on the school performance of natives is higher in countries where the segregation of immigrants in schools is higher. However, the quantitative impact of desegregation policies suggested by our estimates is small, as we find that halving the index of segregation would increase the test performance of natives by only 0.86 to 1.28 percent.

The paper is organized as follows: Section 2 is a brief review of the relevant literature and Section 3 presents our empirical approach. The data and the main results are presented in Sections 4 and 5. Section 6 presents some robustness checks and an important extension. Conclusions follow.

\section{Review of the Literature}

\footnotetext{
${ }^{1}$ Borjas (2003), Mishra (2007) and Aydemir and Borjas (2007) among others use a similar strategy to estimate the impact of the share of immigrants on wages.

2 To illustrate, if immigrant students were evenly distributed across the schools in our sample, doubling their share would be equivalent to increasing the number of immigrants from 1 to 2 in classes with about 20 students.
} 
The influence of immigrant students on their native peers is a particular sort of peer effect: immigrants are peers with a different culture, a different way to interact with others and, most often, limited language proficiency. In a recent contribution to the vast literature on peer effects, Lavy et al., 2009, have shown that the effect of peers is not constant but strongest when peers are students either at the very bottom or at the very top of the academic ability distribution. Since immigrant pupils typically perform less well than natives at school for several reasons, including difficulties with the language of instruction, less educated parents and problems of integration, they are often concentrated at the bottom of the distribution of academic ability. According to Lavy's work, their effect on native pupils should be stronger than the effect generated by native peers.

While the economic literature on peer effects in education is extensive, there is surprisingly little being done on the influence of immigrant students on native students. Early contributions include Betts, 1998, and Hoxby, 1998. Betts shows that immigration reduces the probability of completing high-schools for American-native minorities (Blacks and Hispanics). The reason is that an influx of students with limited proficiency in English absorbs teaching resources especially at the expense of those native students who are at the margin of dropping out and typically belong to American minorities. No negative effect of immigrants is found for non minority groups. While Hoxby suggests that immigrant students crowd minority natives out of universities and colleges by competing for scarce remedial resources, Borjas, 2004, finds that the increasing number of immigrant students in the US crowds white American-native males out of universities, especially in elite institutions.

Betts and Fairlie, 2003, find that American native students fly towards private secondary schools in response to the influx of immigrants into public institutions ${ }^{3}$. At least two reasons might explain this flight towards private fee-based schools. First, native households may dislike sending their children to schools that attract immigrants; second, a high share of immigrants may signal to households that the school is low quality.

Gould, Lavy and Paserman, 2009, exploit the mass migration of Jews from the former Soviet Union to Israel in the early 1990s to assess the long run impact of

\footnotetext{
${ }^{3}$ No flight has been observed out of primary schools.
} 
immigrants on native students. They find that a higher share of immigrants in the fifth grade has a negative influence on the probability of passing the final matriculation exam. Their identification strategy is based on the assumption that, conditional on the total number of immigrant students admitted to a given school, the variation in the proportion of immigrants across grades of the same school can be considered as due solely to exogenous demographic factors.

Although not dealing explicitly with migrants, Angrist and Lang, 2004, estimate the impact of a de-segregation program (METCO) carried out in the Boston area, which transferred black students to the "whites only" schools in the more affluent Boston belt. They find no effect of de-segregation on the test scores of white students in the receiving schools and a modest effect on minority students. Non random allocation of black students is addressed by looking at the within-school variation across multiple classes in the same school.

Similarly, Hoxby, 2000, identifies peer effects by exploiting the variation in the composition by gender and race of students attending a particular grade in adjacent years over a sample of schools. She finds that peer effects are stronger within races than across races, meaning that students of a given race are mainly influenced by students of the same race. This result is consistent with the findings by Card and Rothstein's, 2007, indicating that segregation in racially homogenous schools widens the white-black gap in test scores. In their paper, the key issue of student sorting is resolved by aggregating micro-data by race and city and by taking first differences between races in each city. This strategy removes sorting both across schools and across cities.

Hanushek et al. (2002) use panel data on student careers to estimate the peer effect of different racial groups on individual tests scores. Identification is achieved by exploiting the fact that students move from one school to another (about 20\% of the entire sample). Their results show that a higher share of black schoolmates has a strong adverse effect on the achievement of blacks. In contrast, racial composition has a noticeably smaller effect on achievement of whites and Hispanics. Finally, Ammermuller and Pischke, 2006, investigate whether students are randomly allocated across classes of the same school or whether there exists ability grouping. They 
conclude that allocation is non-random for immigrant students and that classes with more immigrant students tend to have better teachers ${ }^{4}$.

\section{The empirical setup}

We address the endogenous sorting of students across schools and classes by aggregating data at the country level. We use repeated country observations over time and identify the relationship between the share of immigrants and the test scores of natives by exploiting the country by time variations in the data. Our empirical model is

$$
y_{c r t}=\theta m_{c t}+\beta X_{c t}+\phi_{c}+\phi_{t}+\phi_{r}+\varepsilon_{c r t}
$$

where $y$ is the test score of 15 years - old native pupils in subject $r, m$ is the average share of their 15 years - old immigrant peers in country $c$ and time $t, X$ is a vector of additional country by time controls and $\phi_{c}, \phi_{t}$ and $\phi_{r}$ are country, time and subject effects, which we capture with country, time and subject dummies. While aggregation allows us to sidestep the problems generated by the sorting of students among schools, it does not eliminate the selection of immigrants across countries of destination. For instance, positive school expenditure shocks affecting a country could increase test scores and at the same time attract more immigrants in the country if additional expenditure is induced by higher income per capita.

This type of selection is captured in part by country and time dummies. To control for country by time effects, we include in the vector $X$ the growth rate and the level of real GDP per capita as well as secondary school expenditure per pupil as percentage of GDP per capita. We also condition on the total stock of immigrants in the country. Conditional on this stock, the share of immigrant pupils who are in school at age 15 in a given country is mainly determined by demographic factors and is as good as random. By conditioning on the stock of immigrants, we implement at the country level the approach used by Gould, Lavy and Paserman, 2009, at the school level, with an important difference: while they need to worry about the residual correlation between

\footnotetext{
${ }^{4}$ In a recent paper, Neymotin, 2009, looks at the effect of immigrants on SAT scores of native Americans and finds evidence of a positive relationship.
} 
the share of immigrants and unobserved school characteristics, we control for unobserved country characteristics in a flexible way by using country dummies ${ }^{5}$.

Parameter $\theta$ in equation (1) measures the marginal effect of the average share of immigrant pupils on the average test score of 15 years - old native students. The linear specification does not consider the fact that - conditional on the mean share of immigrant pupils - the average test score of natives could vary with the distribution of immigrants within each country and among schools. In particular, average test scores could be lower - for a given average share of immigrants - when immigrant pupils concentrate in a few schools than when they are evenly distributed across all schools. To capture this distributional effect, we compute the segregation index (see Duncan and Duncan, 1995)

$$
D_{c t}=\frac{1}{2} \sum_{s=1}^{S}\left|\frac{I_{s c t}}{I_{c t}}-\frac{N_{s c t}}{N_{c t}}\right|
$$

where $s$ is for the school, $I$ the number of 15 years - old immigrant pupils and $N$ the number of native pupils in the same age group. The index ranges between 0 (equal distribution) and 1 (full segregation). We try to capture the effects of segregation at the country level by adding to (1) both the index D and its interaction with the share of immigrant pupils.

How does the marginal effect in (1) relate to the marginal effect at the school level? To illustrate this relationship, consider a country with $N$ native and $M$ immigrant students enrolled in $S$ schools. Let $y_{s}$ be the average performance of native students attending school $s$ and approximate the share of immigrant students in school $s$ with the ratio $M_{s} / N_{s}$, where $M_{s}$ and $N_{s}$ are immigrant and native students in school $s$. Furthermore, let the performance of natives in school $s$ depend linearly on school characteristics and on the share of immigrants according to

\footnotetext{
${ }^{5}$ Gould, Lavy and Paserman also control for school size by including in their regressions the total number of students enrolled in the 5th grade. We do not include in our regressions the country - specific population of students because we expect that, conditional on country fixed effects and the total number of immigrants, the residual country by time variation in the population of students aged 15 is very small.
} 


$$
y_{s}=\mu_{s}+\beta_{s} \frac{M_{s}}{N_{s}}
$$

where the marginal effect $\beta_{s}$ is allowed to vary among schools. Aggregation of (3) at the country level yields

$$
y=\frac{1}{N} \sum_{s} N_{s} y_{s}=\frac{1}{N} \sum_{s} N_{S}\left(\mu_{S}+\beta_{s} \frac{M_{S}}{N_{S}}\right)=\mu+\frac{M}{N}\left(\sum_{S} \frac{M_{S}}{M} \beta_{S}\right)=\mu+\beta \frac{M}{N}
$$

The country - specific marginal effect $\beta$ turns out to be the weighted average of the school - specific marginal effects $\beta_{s}$ in schools with a strictly positive number of immigrant students ${ }^{6}$.

\section{The Data}

We use data from the four available waves - 2000, 2003, 2006 and 2009 - of the OECD Programme for International Student Assessment (PISA). PISA is a large scale project that measures the cognitive abilities of 15 years - old students, using standardized tests that focus on reading, mathematics and science skills. The project compares average scores across countries, but also monitors trends over time in student performance. Each wave focuses on a major domain (reading, maths or science) and treats the rest as minor domains. As suggested by PISA technical reports, we enhance the comparability over time for each domain by retaining only the wave where it is treated as major and the following waves ${ }^{7}$. Therefore, we use all four waves for reading and exclude wave 2000 for maths and waves 2000 and 2003 for science.

We define immigrant students as pupils born abroad from two foreign parents. A broader definition adds those born in the country from foreign parents (second generation immigrants). PISA data include information on parental background, such as

\footnotetext{
${ }^{6}$ Equation (4) holds in first approximation ( $\ln y_{s} \cong y_{s}-1$ ) when the dependent variable is the log of school performance.

${ }^{7}$ See OECD, Comparison over Time on the PISA Scales, Paris, 2007.
} 
the educational attainment of each parent and the number of books in the household. Following Wossmann, 2005, we select the latter indicator to capture country by time variations in environmental factors affecting test score performance ${ }^{8}$.

PISA assesses students aged between 15 years and 3 (complete) months and 16 years and 2 (complete) months at the beginning of the assessment period, who are enrolled in an educational institution at grade 7 or higher. The sample is two-stage stratified: in the first stage, schools are randomly selected in each country. In the second stage, 35 students are randomly selected from each school. The sampling standards used in PISA permit countries to exclude up to 5 percent of the relevant population, either by excluding schools (up to 2.5 percent) or by excluding students (up to 2.5 percent of the relevant population). One exclusion criterion is that the student has limited proficiency in the assessment language ${ }^{9}$. Since immigrants are most likely to have insufficient language experience, this sampling design implies that the measured share of immigrants in the school is likely to be under-estimated. We use the information provided by PISA at the country level both on the weighted number of students excluded because of language problems and on the weighted number of participating students to correct this bias in the measure of the share of immigrants, under the plausible assumption that students excluded because of language problems are typically immigrants.

As discussed at length by Aydemir and Borjas, 2010, sampling error in the measure of the share of immigrants can lead to substantial attenuation of the estimated effect of immigration on test scores. This bias can be particularly relevant in setups that use longitudinal information and control for fixed effects, as in the current study. Aydemir and Borjas suggest strategies to deal with this problem, which include instrumental variables estimation.

We exclude from the sample the countries with an average share of immigrant pupils in schools below 1 percent in all the four waves (Japan, Korea among others) and with less than two observations on the share of immigrants (Singapore among others). Additional countries, including Lichtenstein, Argentina and Macao, are excluded because of missing data for the selected controls in vector $X$. We also exclude

\footnotetext{
${ }^{8}$ PISA produces a qualitative indicator of the number of books, that ranges from 1 ( $0-10$ books) to 6 (more than 500 books).

${ }^{9}$ An additional criterion for exclusion is disability. See PISA Technical Report 2006, OECD, Paris.
} 
Luxembourg and Hong Kong because of their limited size. We end up with a sample of 27 countries, mainly from Europe and the Anglo-Saxon world. Selected summary statistics by country are reported in Table 1 . The share of first generation 15 years -old immigrant students (born abroad from foreign parents) is close to or above 10 percent in Switzerland, Australia and New Zealand and below 2 percent in Latvia, Hungary, Finland and Mexico. The other countries lie in between these two extremes. The average share in our sample is 4.8 percent, with a standard deviation equal to 0.035 . While two thirds of the total variation in this share occurs between countries, one third takes place within countries and over time.

As shown in Figure 1, there is a clear negative correlation between the share of immigrant pupils and the segregation index. For instance, countries such as New Zealand, where the share of immigrant pupils is relatively high, have a relatively more homogeneous distribution of immigrants across schools than Finland, where immigrant pupils are few. Table 1 shows that correcting the share of immigrants with the percentage of excluded pupils produces small adjustments. The addition of second generation immigrants (born in the country from foreign parents) increases substantially the adjusted share of immigrant students, which is equal on average to 9.9 percent (standard deviation: 0.067) and reaches 15 percent or above in Switzerland, Australia and New Zealand, the US, Israel and Germany.

We collect data on GDP per capita measured in 2005 US dollars and on the expenditure per pupil in secondary education as percentage of GDP per capita from the World Bank World Development Indicators. The stock of immigrants by country and year is drawn instead from the UN Department of Economic and Social Affairs Population Division ${ }^{10}$.

\section{The Results}

We pool the data for the 27 countries, four waves and three domains (reading, maths and science) and obtain a final sample of 238 observations. Since the share of immigrants in equation (1) is at a higher level of aggregation than test scores, we cluster standard errors by country and time, and add to the variables in vector $X$ the average

\footnotetext{
${ }^{10}$ Trends in the International Migrant Stock: The 2008 Revision
} 
share of 15 years - old male pupils and an indicator of the average number of books. In all specifications we use the log test score as the dependent variable. In the baseline specification we apply no correction to the share of immigrant pupils, which refers to students born abroad from foreign parents ${ }^{11}$. Table 2 presents our estimates. The dependent variable in column (1) is the log average test score attained by 15 years - old native pupils. In columns (2) and (3) we distinguish between male and female natives, and in columns (4) and (5) we consider separately native pupils with a "good" and "poor" parental background, where "good" is for students who have a number of books in the household higher than or equal to the country mean, and "poor" is for those with fewer books.

We find that the share of immigrant pupils attracts a negative and statistically significant coefficient (at least at the 10 percent level of confidence) in all the specifications in the table, except the one for natives with good parental background. The estimated effect is larger for females than for males and for natives with poor parental background than for better endowed pupils. While the former difference is not statistically significant at the 5 percent level of confidence, the latter is ${ }^{12}$. The size of the estimated effect is small: a one percentage point increase in the share of immigrant students is expected to reduce the average test scores of natives by 0.275 percent in the full sample. This implies that doubling the share of immigrant pupils from the average 4.8 percent to close to 10 percent reduces the average test score of natives by only 1.32 to 1.96 percent. The largest effect is obtained in the case of native students with a relatively poor parental background.

The small effect of the immigrant share on the test score of native pupils could be due, at least in part, to attenuation bias induced by measurement error. As argued by Aydemir and Borjas, 2010, the use of fixed effects in our panel of countries implies that there is little identifying variation left in the share of immigrant pupils, and that any measurement error in this share tends to play a disproportionately large role. We deal with this problem in two different ways. First, we use a corrected measure of the share of immigrants, obtained by adding to this share the percentage of students who were

\footnotetext{
${ }^{11}$ The log-linear specification improves the goodness of fit of the estimates with respect to the linear specification.

${ }^{12}$ The test for gender differences in the marginal effect of the share of immigrants on the test scores of natives has p-value equal to 0.337 . On the other hand, the p-value of the test for parental background differences is equal to 0.000 .
} 
excluded because of language barriers. Table 3 presents our estimates when the corrected measure is used. We find that the estimated effect of the share of immigrant pupils is slightly smaller in absolute value than in Table 2 and less precisely estimated in some specifications (columns (1) and (2)).

Second, we implement the IV strategy suggested by Aydemir and Borjas, $2010^{13}$. These authors show that - even when the pre-aggregation sample size is in the order of 5000 observations per cell - the attenuation bias due to sampling error is about 10-15 percent and increases exponentially when the sample declines, reaching 100 percent with 500 observations per cell. Among the several methods suggested by Aydemir and Borjas to correct for the attenuation bias, one of the best performing is an adaptation of the IV strategy typically adopted to correct attenuation bias. The IV approach requires that two measurements of the variable subject to sampling error are available. By construction, while these measures are highly correlated, their measurement errors are not, whatever the error distribution. Therefore, the second measure can be used as instrument for the first. We randomly split the original sample of pupils into two half samples, compute the share of immigrants in both sub-samples and use the immigrant share in the second-half sample as instrument for the immigrant share of the first-half sample ${ }^{14}$. The procedure is repeated 500 times to derive the empirical distribution of the parameter of interest. As shown in Table 4, we find that the absolute value of the estimated coefficients is only marginally larger than the estimates in the baseline Table 2. Therefore, attenuation bias is a minor problem in the current context ${ }^{15}$.

We investigate whether the average test scores of natives are affected by the distribution of immigrant pupils in the schools of each country by estimating equation (1) augmented with the segregation index $D$ and its interaction with the share $m^{16}$. After

\footnotetext{
${ }^{13}$ This strategy can only be applied to the raw share, because the information required to compute the corrected share is only available at the country level.

${ }^{14}$ This is an application of the unbiased split sample instrumental variable (USSIV) method proposed by Angrist and Krueger (1995).

${ }^{15}$ A similar conclusion can be reached if we apply the analytical formula provided by Aydemir and Borjas (2010, p. 12) to compute an approximate assessment of the sampling error bias. With an average cell size of 8001 observations (median: 4950 observations) and 105 cells, the expected sampling error bias is only 4.4 percent. Notice that Aydemir and Borjas recommend to use this formula in settings with at least 50-100 cells. Since our case is close to the boundary, we prefer to use the IV method discussed in the text.

${ }^{16}$ Since PISA provides data on excluded students only at the national level, we miss the information required to correct the segregation index. Therefore, we use the uncorrected measure of the share of
} 
some experimentation, we find that the most parsimonious specification includes only the interaction between the share and the index. Table 5 presents the OLS estimates and Table 6 the IV estimates based on the approach suggested by Aydemir and Borjas.

It turns out that the interaction of the share of immigrant pupils with $D$ attracts a negative and statistically significant coefficient in all specifications but the one for natives with a good parental background. Hence, a reduction in the share of immigrants has a larger positive effect on the test scores of natives when the segregation index is higher. Again, the estimated effect is small: when we consider the estimates in the first column of Table 5 and evaluate the marginal effect of $m$ at the country-specific values of $D$, we find that one additional percentage point in the share of immigrants reduces the school performance of natives by about 0.5 percent in Latvia, Czech Republic and Mexico, the three countries with the highest $D$, and by about 0.3 percent in Switzerland, Russia and New Zealand, the three countries with lowest segregation.

Our estimates also show that average test scores are higher when the share of educational expenditure per student on GDP per capita and the average number of books are higher. No statistically significant effect is found instead for real GDP per capita and its growth and for the stock of immigrants. There is also evidence that the average share of boys in schools has a positive effect on the average math test scores of natives ${ }^{17}$. This result is at odds with the findings by Hoxby, 2000, and Lavy and Schlosser, 2007. The latter study, for instance, finds that educational outcomes in Israel primary, middle and high schools are higher when the proportion of boys is smaller ${ }^{18}$.

\section{Robustness and extensions}

Our estimates of equation (1) assume that the effect of the share of immigrants on the test scores of natives is homogeneous across countries. We have relaxed this assumption by allowing the size of the effect to vary with the index of segregation $D$. We have also replicated our estimates of equation (1) on the sub-sample of countries for

immigrants, both in schools and at the country level, and rely on our previous finding that correcting the share of immigrants has minor effects on the estimates.

${ }^{17}$ We also interact subject dummies with the number of books and the share of immigrants but find that these interactions are never jointly different from zero.

${ }^{18}$ Whitmore, 2005, finds mixed results when studying performance in US kindergarten and primary schools. She uses the gender variation generated by the random assignment of students into classrooms in the Tennessee's Project STAR. 
which the null hypothesis of a common effect of the share of immigrants is not rejected. It turns out that the marginal effect of $m$ on $y$ is negative, statistically significant and close to the value shown in the first column of Table 2 . We infer from this that failure to allow for heterogeneous effects has rather marginal consequences on our results ${ }^{19}$.

In our empirical estimates we have used a log-linear specification, which gives a better fit than a linear specification. Not reported here, we have also estimated a linear specification, with no relevant changes in the size of the estimated elasticity of native test scores with respect to the share of immigrant pupils.

Finally, we consider in Table 7 a broader definition of immigrant pupils, which includes also the 15 years - old students who are born in the country from foreign parents (second generation immigrants). On the one hand, since these students are more integrated than first generation immigrants, the negative effect on the performance of natives could be lower in absolute value when we use this broader definition. On the other hand, the negative effect could be higher, not lower, if the marginal effect of the share of immigrants on the performance of natives increases with the share of immigrants. We compare our estimates in Table 3 and 7 and conclude that using a broader definition of immigrant pupils changes only slightly the marginal effect of the share of immigrant pupils on the test scores of natives.

\section{Conclusions}

The proportion of immigrant students has increased over time in most developed countries, especially during the last two decades. Many parents and politicians fear that too many immigrant students could have a negative influence on the school performance of natives, either because of negative peer effects or because immigrants with their limited proficiency in the language of the host country - can reduce teacher attention for natives. In Italy, for instance, the Education Minister has taken public sentiment very seriously and established a threshold of 30 percent to the number of immigrant pupils in Italian classes.

\footnotetext{
${ }^{19}$ The estimated coefficient of $m$ in the sub-sample of countries for which pooling is not rejected from a statistical point of view is -0.226 , smaller in absolute value but rather close to the coefficient reported in Table 2.
} 
Is this fear supported by empirical evidence? Using cross country aggregate data from the PISA project, we have reached the following conclusions. First, there is evidence that a higher share of immigrant pupils in secondary schools reduces the test scores of natives, especially those with a relatively disadvantaged parental background. The size of the effect, however, is small and varies with the sub-group of natives. Our cross country estimates suggest that doubling the share of immigrant pupils in a country reduces the average test scores of 15 years - old male and female natives in secondary schools by 1.3 and 1.7 percent respectively. This effect is slightly higher (about 2 percent) for natives with disadvantaged parental background. Second, there is evidence that the marginal effect of the share of immigrant pupils on the test score of natives is higher in absolute value, but still small in size, in those countries where immigrants are concentrated in few schools and the segregation index is higher.

We have also shown that the negative effect of immigrant students on natives is not borne within each country by all native students to the same extent. To further illustrate this point, we notice that, in our sample of countries, about 51 percent of all native students have no immigrant peers in their schools, and the average proportion of immigrant students in the schools attended by at least some immigrants is 11.3 percent. As a thought experiment, consider two hypothetical schools in a country, equal in all respects except for the share of immigrant students, equal to zero in first and to 11.3 percent in the second school. Our baseline estimates in Table 2 suggest that the test scores of natives are 1.93 to 4.62 percent lower in the second school because of the presence of immigrant students.

This gap is much larger when we compare a school belonging to the top decile of the distribution of the share of immigrants with a school without immigrants. In countries where the share of immigrant students in the schools of the top decile is high Austria, Greece, Israel, Switzerland and New Zealand - the estimated gap in the test scores of natives with schools having no immigrants can exceed 10 percent and is close to 20 percent when we focus on the sub-sample of natives with poor family background. These are the students who typically end up in schools with a high percentage of immigrants and who would benefit substantially by reallocation to schools without immigrant pupils. 


\section{References}

Ammermueller, A. and Pischke, J.S. (2006) "Peer Effects In European Primary Schools: Evidence From PIRLS”, NBER working paper n.12180

Angrist, J.D. and Lang, K. (2004) "Does School Integration Generate Peer Effects? Evidence from Boston's Metco Program”, The American Economic Review, 94(5): 16131634

Aydemir, Abdurrahman, and George J. Borjas. 2007. A comparative analysis of the labor market impact of international migration: Canada, Mexico, and the United States. Journal of the European Economic Association 5, no. 4:663-708

Betts, J.R. (1998) "Educational crowding out: do immigrants affect the educational attainment of American minorities?" in: Hamermesh, D.S., Bean, F.D. (Eds.), "Help or Hindrance? The Economic Implications of Immigration for African-Americans". Russell Sage Foundation, New York.

Betts, J.R. and Fairlie, R.W. (2003) "Does immigration induce 'native flight' from public schools into private schools?” Journal of Public Economics 87:987-1012

Borjas, George J. 2003. The labor demand curve is downward sloping: reexamining the impact of immigration on the labor market. Quarterly Journal of Economics 118, no. 4:1335-1374.

Borjas, G.J. (2004) "Do Foreign Students Crowd Out Native Students From Graduate Programs?”, NBER Working Paper 10349

David Card, D. and Rothstein, Jesse (2007) "Racial Segregation and the Black-White Test Score Gap”, Journal of Public Economics, 91:2158-2184

Dias, B. , Farinha, T., Freitas, I., Ribeiro, M., Rosário, E., Seabra, H., And Silva, E. (2005) “The Situation Of Immigrants And Ethnic Minorities In Portugal In 2005” Annual Report For The European Monitoring Centre On Racism And Xenophobia

Gould E.D., Lavy V. and Paserman M.D. (2009) "Does Immigration Affect the Long Term Educational Outcomes of Natives? Quasi-experimental Evidence”, The Economic Journal, 119: 1243-1269.

Hanushek, E.A., Kain J.F. and Rivkin, S.G. (2002) "New Evidence About Brown V. Board Of Education: The Complex Effects Of School Racial Composition On Achievement", NBER working paper n.8741

Hoxby, C.M. (1998) "Do immigrants crowd disadvantaged American natives out of higher education?” in: Hamermesh, D.S., Bean, F.D. (Eds.), “Help or Hindrance? The Economic Implications of Immigration for African-Americans”. Russell Sage Foundation, New York.

Hoxby, C.M. (2000) "Peer Effects in Classroom: Learning from Gender and Race Variation”, NBER working paper, n.7867

Lavy, V. and Schlosser, A. (2007), "Mechanisms And Impacts Of Gender Peer Effects At School”, NBER working paper, n.13292

Lavy, V., Silva, O., and Weinhardt, F. (2009) "The Bad, The Good, And The Average: Evidence On The Scale And Nature Of Ability Peer Effects In Schools”, NBER working paper n.15600 
Manski, C.F. (1993) "Identification of Endogenous Social Effects: The Reflection Problem”, The Review of Economic Studies, 60(3):531-542

Mishra, Prachi. 2007. Emigration and wages in source countries: evidence from Mexico. Journal of Development Economics 82, no. 1:180-199.

Padilla, B. (2005) "Integration of Brazilian immigrants in Portuguese Society: Problems and Possibilities” SOCIUS Working Papers 1/2005

Sacerdote, B. (2001) "Peer Effects With Random Assignment: Results For Dartmouth Roommates”, The Quarterly Journal of economics, 116(2):681-704

Whitmore, Diane, (2005), "Resource and Peer Impacts on Girls' Academic Achievement: Evidence from a Randomized Experiment”, American Economic Review Papers and Proceedings, 95(2), pp. 199-203.

Wossmann, L. and West, M. (2006) "Class-size effects in school systems around the world: Evidence from between-grade variation in TIMSS”, European Economic Review 50:695736 
Table 1 . Test scores and the share of immigrant pupils; by country

\begin{tabular}{|c|c|c|c|c|c|}
\hline Country & Test score & $\begin{array}{l}\% \text { immigrant } \\
\text { students }\end{array}$ & $\begin{array}{l}\text { \% immigrant } \\
\text { students - } \\
\text { corrected }\end{array}$ & $\begin{array}{l}\text { \% immigrant students } \\
\text { - broader definition }\end{array}$ & $\begin{array}{l}\text { Segregation } \\
\text { index }\end{array}$ \\
\hline Australia & 522.2 & 0.102 & 0.105 & 0.221 & 0.494 \\
\hline Austria & 507.5 & 0.067 & 0.073 & 0.138 & 0.551 \\
\hline Belgium & 526.0 & 0.057 & 0.060 & 0.129 & 0.598 \\
\hline Switzerland & 529.4 & 0.098 & 0.104 & 0.221 & 0.442 \\
\hline Canada & 533.3 & 0.097 & 0.104 & 0.211 & 0.689 \\
\hline Czech Rep. & 500.8 & 0.008 & 0.009 & 0.018 & 0.815 \\
\hline Germany & 519.9 & 0.065 & 0.068 & 0.145 & 0.521 \\
\hline Denmark & 506.9 & 0.030 & 0.039 & 0.081 & 0.595 \\
\hline Spain & 486.8 & 0.054 & 0.066 & 0.074 & 0.607 \\
\hline Finland & 549.0 & 0.014 & 0.017 & 0.022 & 0.769 \\
\hline France & 506.9 & 0.030 & 0.032 & 0.127 & 0.662 \\
\hline Greece & 471.3 & 0.060 & 0.062 & 0.077 & 0.631 \\
\hline Hungary & 491.1 & 0.014 & 0.015 & 0.019 & 0.702 \\
\hline Ireland & 508.7 & 0.042 & 0.046 & 0.057 & 0.481 \\
\hline Iceland & 501.3 & 0.012 & 0.021 & 0.023 & 0.712 \\
\hline Italy & 480.0 & 0.028 & 0.033 & 0.040 & 0.629 \\
\hline Israel & 455.2 & 0.085 & 0.089 & 0.196 & 0.581 \\
\hline Latvia & 486.9 & 0.006 & 0.006 & 0.060 & 0.856 \\
\hline Mexico & 415.2 & 0.015 & 0.016 & 0.022 & 0.802 \\
\hline Netherlands & 531.8 & 0.034 & 0.034 & 0.111 & 0.548 \\
\hline Norway & 500.9 & 0.031 & 0.038 & 0.066 & 0.577 \\
\hline New Zealand & 528.6 & 0.144 & 0.160 & 0.227 & 0.473 \\
\hline Portugal & 480.9 & 0.027 & 0.030 & 0.052 & 0.650 \\
\hline Russia & 466.0 & 0.048 & 0.048 & 0.096 & 0.471 \\
\hline Sweden & 513.0 & 0.046 & 0.052 & 0.115 & 0.596 \\
\hline UK & 508.1 & 0.035 & 0.038 & 0.089 & 0.692 \\
\hline USA & 498.4 & 0.058 & 0.065 & 0.162 & 0.634 \\
\hline
\end{tabular}

Note: col. 1: average score in reading, mathematics and science over the selected waves. col. 2: average share of immigrant pupils aged 15; col. 3: corrected average share of immigrant pupils. col. 4: corrected average share of immigrants, including those born in the country from foreign parents. Source: PISA 
Table 2. OLS estimates of the effects of the share of migrants on the test score of natives. Dependent variable: $\log$ test scores.

\begin{tabular}{|c|c|c|c|c|c|}
\hline VARIABLES & $\begin{array}{l}\text { (1) } \\
\text { All }\end{array}$ & $\begin{array}{l}(2) \\
\text { Males }\end{array}$ & $\begin{array}{c}(3) \\
\text { Females }\end{array}$ & $\begin{array}{c}\text { (4) } \\
\text { Good } \\
\text { Parental } \\
\text { Background } \\
\end{array}$ & $\begin{array}{c}(5) \\
\text { Poor Parental } \\
\text { Background }\end{array}$ \\
\hline Share of immigrant pupils (marginal effect) & $\begin{array}{c}-0.275^{* *} \\
(0.135)\end{array}$ & $\begin{array}{l}-0.255^{*} \\
(0.145)\end{array}$ & $\begin{array}{c}-0.326 * * \\
(0.141)\end{array}$ & $\begin{array}{l}-0.171 \\
(0.123)\end{array}$ & $\begin{array}{l}-0.409 * * * \\
(0.155)\end{array}$ \\
\hline $\begin{array}{l}\text { Education expenditure per capita } \\
\text { as \% of GDP per capita }\end{array}$ & $\begin{array}{l}0.001^{* *} \\
(0.000)\end{array}$ & $\begin{array}{l}0.001^{* *} \\
(0.000)\end{array}$ & $\begin{array}{l}0.001^{* *} \\
(0.000)\end{array}$ & $\begin{array}{l}0.001^{*} \\
(0.000)\end{array}$ & $\begin{array}{c}0.001^{* * *} \\
(0.000)\end{array}$ \\
\hline Growth rate of real GDP per capita & $\begin{array}{c}0.041 \\
(0.036)\end{array}$ & $\begin{array}{c}0.047 \\
(0.038)\end{array}$ & $\begin{array}{c}0.031 \\
(0.037)\end{array}$ & $\begin{array}{l}0.072^{* *} \\
(0.029)\end{array}$ & $\begin{array}{l}-0.007 \\
(0.042)\end{array}$ \\
\hline Real GDP per capita & $\begin{array}{l}-0.003 \\
(0.002)\end{array}$ & $\begin{array}{l}-0.003 \\
(0.002)\end{array}$ & $\begin{array}{l}-0.003 \\
(0.002)\end{array}$ & $\begin{array}{l}-0.001 \\
(0.002)\end{array}$ & $\begin{array}{l}-0.002 \\
(0.002)\end{array}$ \\
\hline Average number of books in household & $\begin{array}{c}0.032 \\
(0.020)\end{array}$ & $\begin{array}{l}0.035^{*} \\
(0.020)\end{array}$ & $\begin{array}{l}0.033^{*} \\
(0.018)\end{array}$ & $\begin{array}{c}0.049 * * * \\
(0.008)\end{array}$ & $\begin{array}{c}0.066^{* * *} \\
(0.012)\end{array}$ \\
\hline Total stock of immigrants & $\begin{array}{c}0.000 \\
(0.002)\end{array}$ & $\begin{array}{c}0.001 \\
(0.003)\end{array}$ & $\begin{array}{l}-0.002 \\
(0.002)\end{array}$ & $\begin{array}{l}-0.002 \\
(0.002)\end{array}$ & $\begin{array}{c}0.001 \\
(0.003)\end{array}$ \\
\hline Percentage boys & $\begin{array}{c}0.052 \\
(0.120)\end{array}$ & $\begin{array}{c}0.007 \\
(0.133)\end{array}$ & $\begin{array}{l}0.240^{*} \\
(0.121)\end{array}$ & $\begin{array}{c}0.095 \\
(0.122)\end{array}$ & $\begin{array}{c}0.111 \\
(0.147)\end{array}$ \\
\hline Percentage boys * Mathematics & $\begin{array}{c}0.658^{* * *} \\
(0.194)\end{array}$ & $\begin{array}{c}0.590 * * * \\
(0.187)\end{array}$ & $\begin{array}{c}0.544^{* *} \\
(0.220)\end{array}$ & $\begin{array}{c}0.590^{* * * *} \\
(0.179)\end{array}$ & $\begin{array}{c}0.698 * * * \\
(0.214)\end{array}$ \\
\hline Percentage boys * Science & $\begin{array}{c}0.366^{*} \\
(0.198)\end{array}$ & $\begin{array}{c}0.366 \\
(0.226)\end{array}$ & $\begin{array}{c}0.210 \\
(0.180)\end{array}$ & $\begin{array}{c}0.324^{*} \\
(0.174)\end{array}$ & $\begin{array}{c}0.431^{*} \\
(0.226)\end{array}$ \\
\hline $\begin{array}{l}\text { Observations } \\
\text { R-squared }\end{array}$ & $\begin{array}{c}238 \\
0.924\end{array}$ & $\begin{array}{c}238 \\
0.933\end{array}$ & $\begin{array}{c}238 \\
0.924\end{array}$ & $\begin{array}{c}238 \\
0.927\end{array}$ & $\begin{array}{c}238 \\
0.906\end{array}$ \\
\hline
\end{tabular}

Notes: each regression includes country, subject and time dummies. Robust standard errors clustered by country and time within parentheses. ${ }^{* * *}, * *, *$ when estimated coefficients are statistically significant at the 1,5 and 10 percent level of confidence. 
Table 3. OLS estimates of the effects of the corrected share of migrants on the test score of natives. Dependent variable: $\log$ test scores.

\begin{tabular}{|c|c|c|c|c|c|}
\hline VARIABLES & $\begin{array}{l}(1) \\
\text { All }\end{array}$ & $\begin{array}{c}(2) \\
\text { Males }\end{array}$ & $\begin{array}{c}(3) \\
\text { Females }\end{array}$ & $\begin{array}{c}(4) \\
\text { Good } \\
\text { Parental } \\
\text { Background } \\
\end{array}$ & $\begin{array}{c}(5) \\
\text { Poor Parenta } \\
\text { Background }\end{array}$ \\
\hline $\begin{array}{l}\text { Corrected share of immigrant pupils } \\
\text { (marginal effect) }\end{array}$ & $\begin{array}{l}-0.238^{*} \\
(0.133)\end{array}$ & $\begin{array}{l}-0.203 \\
(0.146)\end{array}$ & $\begin{array}{c}-0.287 * * \\
(0.135)\end{array}$ & $\begin{array}{l}-0.226^{*} \\
(0.129)\end{array}$ & $\begin{array}{c}-0.392^{* *} \\
(0.170)\end{array}$ \\
\hline $\begin{array}{l}\text { Education expenditure per capita } \\
\text { as \% of GDP per capita }\end{array}$ & $\begin{array}{l}0.001^{* *} \\
(0.000)\end{array}$ & $\begin{array}{l}0.001^{*} \\
(0.000)\end{array}$ & $\begin{array}{c}0.001 * * \\
(0.000)\end{array}$ & $\begin{array}{c}0.001 \\
(0.000)\end{array}$ & $\begin{array}{l}0.001^{*} \\
(0.001)\end{array}$ \\
\hline Growth rate of real GDP per capita & $\begin{array}{c}0.041 \\
(0.036)\end{array}$ & $\begin{array}{c}0.047 \\
(0.038)\end{array}$ & $\begin{array}{c}0.031 \\
(0.037)\end{array}$ & $\begin{array}{l}0.072 * * \\
(0.029)\end{array}$ & $\begin{array}{l}-0.007 \\
(0.042)\end{array}$ \\
\hline Real GDP per capita & $\begin{array}{c}0.039 \\
(0.037)\end{array}$ & $\begin{array}{l}0.046 \\
(0.039)\end{array}$ & $\begin{array}{c}0.027 \\
(0.037)\end{array}$ & $\begin{array}{c}0.068 \\
(0.041)\end{array}$ & $\begin{array}{l}-0.005 \\
(0.062)\end{array}$ \\
\hline Average number of books in household & $\begin{array}{l}-0.003 \\
(0.002)\end{array}$ & $\begin{array}{l}-0.003 \\
(0.002)\end{array}$ & $\begin{array}{l}-0.003 \\
(0.002)\end{array}$ & $\begin{array}{l}-0.003 \\
(0.002)\end{array}$ & $\begin{array}{l}-0.004^{*} \\
(0.002)\end{array}$ \\
\hline Total stock of immigrants & $\begin{array}{c}0.031 \\
(0.020)\end{array}$ & $\begin{array}{c}0.033 \\
(0.020)\end{array}$ & $\begin{array}{c}0.028 \\
(0.019)\end{array}$ & $\begin{array}{l}0.027 \\
(0.020)\end{array}$ & $\begin{array}{c}0.022 \\
(0.028)\end{array}$ \\
\hline Percentage boys & $\begin{array}{c}0.046 \\
(0.120)\end{array}$ & $\begin{array}{l}-0.003 \\
(0.133)\end{array}$ & $\begin{array}{c}0.249 * * \\
(0.121)\end{array}$ & $\begin{array}{c}0.017 \\
(0.135)\end{array}$ & $\begin{array}{l}-0.105 \\
(0.160)\end{array}$ \\
\hline Percentage boys * Mathematics & $\begin{array}{c}0.657 * * * \\
(0.194)\end{array}$ & $\begin{array}{c}0.590 * * * \\
(0.187)\end{array}$ & $\begin{array}{c}0.536 * * \\
(0.219)\end{array}$ & $\begin{array}{c}0.571^{* * * *} \\
(0.181)\end{array}$ & $\begin{array}{c}0.711^{* * *} \\
(0.215)\end{array}$ \\
\hline Percentage boys * Science & $\begin{array}{c}0.367 * \\
(0.199)\end{array}$ & $\begin{array}{c}0.367 \\
(0.226)\end{array}$ & $\begin{array}{c}0.197 \\
(0.178)\end{array}$ & $\begin{array}{c}0.281 \\
(0.188)\end{array}$ & $\begin{array}{c}0.404^{*} \\
(0.239)\end{array}$ \\
\hline $\begin{array}{l}\text { Observations } \\
\text { R-squared }\end{array}$ & $\begin{array}{c}238 \\
0.924\end{array}$ & $\begin{array}{c}238 \\
0.933\end{array}$ & $\begin{array}{c}238 \\
0.923\end{array}$ & $\begin{array}{c}238 \\
0.917\end{array}$ & $\begin{array}{c}238 \\
0.890\end{array}$ \\
\hline
\end{tabular}


Table 4. IV estimates of the effects of the share of migrants on the test score of natives. Averages over 500 replications. Dependent variable: $\log$ test scores.

\begin{tabular}{|c|c|c|c|c|c|}
\hline VARIABLES & $\begin{array}{l}(1) \\
\text { All }\end{array}$ & $\begin{array}{l}(2) \\
\text { Males }\end{array}$ & $\begin{array}{l}(3) \\
\text { Females }\end{array}$ & $\begin{array}{c}\text { (4) } \\
\text { Good } \\
\text { Parental } \\
\text { Background }\end{array}$ & $\begin{array}{c}(5) \\
\text { Poor Parental } \\
\text { Background }\end{array}$ \\
\hline $\begin{array}{l}\text { Share of immigrants in school } \\
\text { (marginal effect) }\end{array}$ & $\begin{array}{l}-0.281 \\
(0.057) \\
{[0.153]}\end{array}$ & $\begin{array}{l}-0.265 \\
(0.068) \\
{[0.165]}\end{array}$ & $\begin{array}{l}-0.330 \\
(0.066) \\
{[0.162]}\end{array}$ & $\begin{array}{l}-0.169 \\
(0.059) \\
{[0.142]}\end{array}$ & $\begin{array}{l}-0.422 \\
(0.070) \\
{[0.178]}\end{array}$ \\
\hline $\begin{array}{l}\text { Education expenditure per capita } \\
\text { as \% of GDP per capita }\end{array}$ & $\begin{array}{c}0.001 \\
(0.000) \\
{[0.000]}\end{array}$ & $\begin{array}{c}0.001 \\
(0.000) \\
{[0.000]}\end{array}$ & $\begin{array}{c}0.001 \\
(0.000) \\
{[0.000]}\end{array}$ & $\begin{array}{c}0.001 \\
(0.000) \\
{[0.000]}\end{array}$ & $\begin{array}{c}0.001 \\
(0.000) \\
{[0.000]}\end{array}$ \\
\hline Growth rate of real GDP per capita & $\begin{array}{c}0.039 \\
(0.017) \\
{[0.038]}\end{array}$ & $\begin{array}{c}0.046 \\
(0.022) \\
{[0.040]}\end{array}$ & $\begin{array}{c}0.027 \\
(0.020) \\
{[0.040]}\end{array}$ & $\begin{array}{c}0.070 \\
(0.021) \\
{[0.032]}\end{array}$ & $\begin{array}{l}-0.009 \\
(0.020) \\
{[0.045]}\end{array}$ \\
\hline Real GDP per capita & $\begin{array}{l}-0.003 \\
(0.000) \\
{[0.002]}\end{array}$ & $\begin{array}{l}-0.003 \\
(0.001) \\
{[0.002]}\end{array}$ & $\begin{array}{l}-0.003 \\
(0.001) \\
{[0.002]}\end{array}$ & $\begin{array}{l}-0.002 \\
(0.001) \\
{[0.002]}\end{array}$ & $\begin{array}{l}-0.003 \\
(0.001) \\
{[0.002]}\end{array}$ \\
\hline $\begin{array}{l}\text { Average number of books in } \\
\text { household }\end{array}$ & $\begin{array}{c}0.031 \\
(0.006) \\
{[0.019]}\end{array}$ & $\begin{array}{c}0.035 \\
(0.008) \\
{[0.019]}\end{array}$ & $\begin{array}{c}0.033 \\
(0.008) \\
{[0.017]}\end{array}$ & $\begin{array}{c}0.048 \\
(0.004) \\
{[0.009]}\end{array}$ & $\begin{array}{c}0.063 \\
(0.004) \\
{[0.013]}\end{array}$ \\
\hline Total stock of immigrants & $\begin{array}{c}0.000 \\
(0.001) \\
{[0.002]}\end{array}$ & $\begin{array}{c}0.002 \\
(0.001) \\
{[0.003]}\end{array}$ & $\begin{array}{l}-0.002 \\
(0.001) \\
{[0.002]}\end{array}$ & $\begin{array}{l}-0.001 \\
(0.001) \\
{[0.002]}\end{array}$ & $\begin{array}{c}0.002 \\
(0.001) \\
{[0.003]}\end{array}$ \\
\hline Percentage boys & $\begin{array}{l}-0.020 \\
(0.089) \\
{[0.121]}\end{array}$ & $\begin{array}{l}-0.035 \\
(0.098) \\
{[0.132]}\end{array}$ & $\begin{array}{c}0.137 \\
(0.092) \\
{[0.125]}\end{array}$ & $\begin{array}{c}0.014 \\
(0.088) \\
{[0.121]}\end{array}$ & $\begin{array}{c}0.013 \\
(0.110) \\
{[0.146]}\end{array}$ \\
\hline Percentage boys * Mathematics & $\begin{array}{c}0.551 \\
(0.087) \\
{[0.180]}\end{array}$ & $\begin{array}{c}0.478 \\
(0.089) \\
{[0.178]}\end{array}$ & $\begin{array}{c}0.441 \\
(0.094) \\
{[0.198]}\end{array}$ & $\begin{array}{c}0.494 \\
(0.083) \\
{[0.167]}\end{array}$ & $\begin{array}{c}0.584 \\
(0.096) \\
{[0.199]}\end{array}$ \\
\hline Percentage boys * Science & $\begin{array}{c}0.312 \\
(0.076) \\
{[0.183]}\end{array}$ & $\begin{array}{c}0.299 \\
(0.084) \\
{[0.209]}\end{array}$ & $\begin{array}{c}0.172 \\
(0.078) \\
{[0.167]}\end{array}$ & $\begin{array}{c}0.276 \\
(0.075) \\
{[0.163]}\end{array}$ & $\begin{array}{c}0.364 \\
(0.088) \\
{[0.209]}\end{array}$ \\
\hline Observations & 238 & 238 & 238 & 238 & 238 \\
\hline
\end{tabular}

Notes: Standard deviation of the empirical distribution of parameters between parentheses. Average standard errors between squared brackets. Each regression includes country, time and subject dummies. Robust standard errors clustered by country and time. 
Table 5. OLS estimates of the effects of the share of migrants and of the segregation index D on the test score of natives. Dependent variable: $\log$ test scores.

\begin{tabular}{|c|c|c|c|c|c|}
\hline VARIABLES & $\begin{array}{l}\text { (1) } \\
\text { All }\end{array}$ & $\begin{array}{c}(2) \\
\text { Males }\end{array}$ & $\begin{array}{l}(3) \\
\text { Females }\end{array}$ & $\begin{array}{c}\text { (4) } \\
\text { Good } \\
\text { Parental } \\
\text { Background } \\
\end{array}$ & $\begin{array}{c}(5) \\
\text { Poor Parenta } \\
\text { Background }\end{array}$ \\
\hline $\begin{array}{l}\text { Share of immigrant pupils } \\
\text { interacted with D (marginal effect) }\end{array}$ & $\begin{array}{l}-0.639 * * \\
(0.288)\end{array}$ & $\begin{array}{l}-0.518^{*} \\
(0.309)\end{array}$ & $\begin{array}{l}-0.834^{* * *} \\
(0.296)\end{array}$ & $\begin{array}{l}-0.329 \\
(0.273)\end{array}$ & $\begin{array}{c}-0.951 * * * \\
(0.328)\end{array}$ \\
\hline $\begin{array}{l}\text { Education expenditure per capita } \\
\text { as \% of GDP per capita }\end{array}$ & $\begin{array}{l}0.001^{* *} \\
(0.000)\end{array}$ & $\begin{array}{c}0.001^{* *} \\
(0.000)\end{array}$ & $\begin{array}{c}0.001^{* * *} \\
(0.000)\end{array}$ & $\begin{array}{l}0.001^{*} \\
(0.000)\end{array}$ & $\begin{array}{c}0.001^{* * *} \\
(0.000)\end{array}$ \\
\hline Growth rate of real GDP per capita & $\begin{array}{c}0.041 \\
(0.036)\end{array}$ & $\begin{array}{c}0.047 \\
(0.038)\end{array}$ & $\begin{array}{c}0.031 \\
(0.037)\end{array}$ & $\begin{array}{l}0.072 * * \\
(0.029)\end{array}$ & $\begin{array}{l}-0.007 \\
(0.042)\end{array}$ \\
\hline Real GDP per capita & $\begin{array}{l}0.035 \\
(0.036)\end{array}$ & $\begin{array}{l}0.043 \\
(0.039)\end{array}$ & $\begin{array}{c}0.023 \\
(0.036)\end{array}$ & $\begin{array}{l}0.069 * * \\
(0.029)\end{array}$ & $\begin{array}{l}-0.016 \\
(0.042)\end{array}$ \\
\hline Average number of books in household & $\begin{array}{l}-0.003 \\
(0.002)\end{array}$ & $\begin{array}{l}-0.003 \\
(0.002)\end{array}$ & $\begin{array}{l}-0.003 * \\
(0.002)\end{array}$ & $\begin{array}{l}-0.001 \\
(0.002)\end{array}$ & $\begin{array}{l}-0.002 \\
(0.002)\end{array}$ \\
\hline Total stock of immigrants & $\begin{array}{c}0.030 \\
(0.019)\end{array}$ & $\begin{array}{l}0.033^{*} \\
(0.020)\end{array}$ & $\begin{array}{l}0.031^{*} \\
(0.017)\end{array}$ & $\begin{array}{c}0.049 * * * \\
(0.008)\end{array}$ & $\begin{array}{c}0.063^{* * *} \\
(0.013)\end{array}$ \\
\hline Percentage boys & $\begin{array}{c}0.040 \\
(0.124)\end{array}$ & $\begin{array}{l}-0.009 \\
(0.137)\end{array}$ & $\begin{array}{l}0.231^{*} \\
(0.125)\end{array}$ & $\begin{array}{c}0.084 \\
(0.125)\end{array}$ & $\begin{array}{c}0.087 \\
(0.152)\end{array}$ \\
\hline Percentage boys * Mathematics & $\begin{array}{c}0.654 * * * \\
(0.194)\end{array}$ & $\begin{array}{c}0.588 * * * \\
(0.188)\end{array}$ & $\begin{array}{c}0.538 * * \\
(0.220)\end{array}$ & $\begin{array}{c}0.588 * * * \\
(0.179)\end{array}$ & $\begin{array}{c}0.693^{* * *} \\
(0.215)\end{array}$ \\
\hline Percentage boys * Science & $\begin{array}{c}0.357^{*} \\
(0.198)\end{array}$ & $\begin{array}{c}0.360 \\
(0.226)\end{array}$ & $\begin{array}{c}0.197 \\
(0.180)\end{array}$ & $\begin{array}{c}0.319 * \\
(0.174)\end{array}$ & $\begin{array}{c}0.417^{*} \\
(0.226)\end{array}$ \\
\hline $\begin{array}{l}\text { Observations } \\
\text { R-squared }\end{array}$ & $\begin{array}{c}238 \\
0.924\end{array}$ & $\begin{array}{c}238 \\
0.933\end{array}$ & $\begin{array}{c}238 \\
0.925\end{array}$ & $\begin{array}{c}238 \\
0.927\end{array}$ & $\begin{array}{c}238 \\
0.906\end{array}$ \\
\hline
\end{tabular}


Table 6. IV estimates of the effects of the share of immigrants interacted with the segregation index D on the test score of natives. Averages over 500 replications. Dependent variable: log test scores.

\begin{tabular}{|c|c|c|c|c|c|}
\hline VARIABLES & $\begin{array}{l}(1) \\
\text { All }\end{array}$ & $\begin{array}{l}(2) \\
\text { Males }\end{array}$ & $\begin{array}{l}(3) \\
\text { Females }\end{array}$ & $\begin{array}{c}\text { (4) } \\
\text { Good } \\
\text { Parental } \\
\text { Background } \\
\end{array}$ & $\begin{array}{c}\text { (5) } \\
\text { Poor Parental } \\
\text { Background }\end{array}$ \\
\hline $\begin{array}{l}\text { Share of immigrants in school } \\
\text { Interacted with segregation index D }\end{array}$ & $\begin{array}{l}-0.708 \\
(0.155) \\
{[0.357]}\end{array}$ & $\begin{array}{l}-0.580 \\
(0.181) \\
{[0.384]}\end{array}$ & $\begin{array}{l}-0.918 \\
(0.180) \\
{[0.373]}\end{array}$ & $\begin{array}{c}-0.357 \\
(0.158) \\
{[0.344]}\end{array}$ & $\begin{array}{c}-1.064 \\
(0.193) \\
{[0.412]}\end{array}$ \\
\hline $\begin{array}{l}\text { Education expenditure per capita } \\
\text { as \% of GDP per capita }\end{array}$ & $\begin{array}{c}0.001 \\
(0.000) \\
{[0.000]}\end{array}$ & $\begin{array}{c}0.001 \\
(0.000) \\
{[0.000]}\end{array}$ & $\begin{array}{c}0.001 \\
(0.000) \\
{[0.000]}\end{array}$ & $\begin{array}{c}0.001 \\
(0.000) \\
{[0.000]}\end{array}$ & $\begin{array}{c}0.001 \\
(0.000) \\
{[0.000]}\end{array}$ \\
\hline Growth rate of real GDP per capita & $\begin{array}{c}0.032 \\
(0.017) \\
{[0.038]}\end{array}$ & $\begin{array}{c}0.041 \\
(0.022) \\
{[0.041]}\end{array}$ & $\begin{array}{c}0.018 \\
(0.020) \\
{[0.039]}\end{array}$ & $\begin{array}{c}0.066 \\
(0.021) \\
{[0.032]}\end{array}$ & $\begin{array}{l}-0.019 \\
(0.020) \\
{[0.045]}\end{array}$ \\
\hline Real GDP per capita & $\begin{array}{l}-0.003 \\
(0.001) \\
{[0.002]}\end{array}$ & $\begin{array}{l}-0.003 \\
(0.001) \\
{[0.002]}\end{array}$ & $\begin{array}{l}-0.003 \\
(0.001) \\
{[0.002]}\end{array}$ & $\begin{array}{l}-0.002 \\
(0.001) \\
{[0.002]}\end{array}$ & $\begin{array}{l}-0.003 \\
(0.001) \\
{[0.002]}\end{array}$ \\
\hline $\begin{array}{l}\text { Average number of books in } \\
\text { household }\end{array}$ & $\begin{array}{c}0.030 \\
(0.006) \\
{[0.019]}\end{array}$ & $\begin{array}{c}0.034 \\
(0.008) \\
{[0.019]}\end{array}$ & $\begin{array}{c}0.032 \\
(0.008) \\
{[0.016]}\end{array}$ & $\begin{array}{c}0.047 \\
(0.004) \\
{[0.009]}\end{array}$ & $\begin{array}{c}0.060 \\
(0.004) \\
{[0.013]}\end{array}$ \\
\hline Total stock of immigrants & $\begin{array}{c}0.001 \\
(0.001) \\
{[0.003]}\end{array}$ & $\begin{array}{c}0.002 \\
(0.001) \\
{[0.003]}\end{array}$ & $\begin{array}{l}-0.001 \\
(0.001) \\
{[0.002]}\end{array}$ & $\begin{array}{l}-0.001 \\
(0.001) \\
{[0.002]}\end{array}$ & $\begin{array}{c}0.003 \\
(0.001) \\
{[0.003]}\end{array}$ \\
\hline Percentage boys & $\begin{array}{l}-0.025 \\
(0.089) \\
{[0.124]}\end{array}$ & $\begin{array}{l}-0.044 \\
(0.097) \\
{[0.135]}\end{array}$ & $\begin{array}{c}0.135 \\
(0.092) \\
{[0.128]}\end{array}$ & $\begin{array}{c}0.008 \\
(0.087) \\
{[0.123]}\end{array}$ & $\begin{array}{c}0.000 \\
(0.110) \\
{[0.149]}\end{array}$ \\
\hline Percentage boys * Mathematics & $\begin{array}{c}0.547 \\
(0.088) \\
{[0.180]}\end{array}$ & $\begin{array}{c}0.476 \\
(0.089) \\
{[0.179]}\end{array}$ & $\begin{array}{c}0.436 \\
(0.093) \\
{[0.198]}\end{array}$ & $\begin{array}{c}0.493 \\
(0.083) \\
{[0.167]}\end{array}$ & $\begin{array}{c}0.580 \\
(0.096) \\
{[0.200]}\end{array}$ \\
\hline Percentage boys * Science & $\begin{array}{c}0.303 \\
(0.076) \\
{[0.185]}\end{array}$ & $\begin{array}{c}0.292 \\
(0.084) \\
{[0.210]}\end{array}$ & $\begin{array}{c}0.160 \\
(0.078) \\
{[0.168]}\end{array}$ & $\begin{array}{c}0.272 \\
(0.075) \\
{[0.164]}\end{array}$ & $\begin{array}{c}0.351 \\
(0.088) \\
{[0.213]}\end{array}$ \\
\hline Observations & 238 & 238 & 238 & 238 & 238 \\
\hline
\end{tabular}


Table 7. OLS estimates of the effects of the corrected share of migrants on the test score of natives. Broader definition of immigrants. Dependent variable: log test scores.

\begin{tabular}{|c|c|c|c|c|c|}
\hline VARIABLES & $\begin{array}{l}\text { (1) } \\
\text { All }\end{array}$ & $\begin{array}{l}(2) \\
\text { Males }\end{array}$ & $\begin{array}{l}(3) \\
\text { Females }\end{array}$ & $\begin{array}{c}(4) \\
\text { Good } \\
\text { Parental } \\
\text { Background } \\
\end{array}$ & $\begin{array}{c}5) \\
\text { Poor Parental } \\
\text { Background }\end{array}$ \\
\hline $\begin{array}{l}\text { Broader share of immigrant pupils } \\
\text { (marginal effect) }\end{array}$ & $\begin{array}{l}-0.259 * \\
(0.136)\end{array}$ & $\begin{array}{l}-0.228 \\
(0.144)\end{array}$ & $\begin{array}{l}-0.304^{* *} \\
(0.137)\end{array}$ & $\begin{array}{l}-0.266^{*} \\
(0.148)\end{array}$ & $\begin{array}{c}-0.423^{* *} \\
(0.205)\end{array}$ \\
\hline $\begin{array}{l}\text { Education expenditure per capita } \\
\text { as \% of GDP per capita }\end{array}$ & $\begin{array}{c}0.001^{* *} \\
(0.000)\end{array}$ & $\begin{array}{l}0.001^{*} \\
(0.000)\end{array}$ & $\begin{array}{c}0.001^{* *} \\
(0.000)\end{array}$ & $\begin{array}{c}0.001 \\
(0.000)\end{array}$ & $\begin{array}{l}0.001^{*} \\
(0.001)\end{array}$ \\
\hline Growth rate of real GDP per capita & $\begin{array}{c}0.041 \\
(0.036)\end{array}$ & $\begin{array}{c}0.047 \\
(0.038)\end{array}$ & $\begin{array}{c}0.031 \\
(0.037)\end{array}$ & $\begin{array}{c}0.072^{* *} \\
(0.029)\end{array}$ & $\begin{array}{l}-0.007 \\
(0.042)\end{array}$ \\
\hline Real GDP per capita & $\begin{array}{l}0.073^{*} \\
(0.038)\end{array}$ & $\begin{array}{l}0.076^{*} \\
(0.040)\end{array}$ & $\begin{array}{l}0.067^{*} \\
(0.039)\end{array}$ & $\begin{array}{c}0.102 * * \\
(0.043)\end{array}$ & $\begin{array}{l}0.050 \\
(0.062)\end{array}$ \\
\hline Average number of books in household & $\begin{array}{l}-0.002 \\
(0.002)\end{array}$ & $\begin{array}{l}-0.002 \\
(0.002)\end{array}$ & $\begin{array}{l}-0.002 \\
(0.002)\end{array}$ & $\begin{array}{l}-0.003 \\
(0.002)\end{array}$ & $\begin{array}{l}-0.004 \\
(0.002)\end{array}$ \\
\hline Total stock of immigrants & $\begin{array}{c}0.033 \\
(0.020)\end{array}$ & $\begin{array}{l}0.034^{*} \\
(0.020)\end{array}$ & $\begin{array}{l}0.030 \\
(0.019)\end{array}$ & $\begin{array}{c}0.029 \\
(0.020)\end{array}$ & $\begin{array}{c}0.025 \\
(0.028)\end{array}$ \\
\hline Percentage boys & $\begin{array}{c}0.037 \\
(0.127)\end{array}$ & $\begin{array}{l}-0.010 \\
(0.139)\end{array}$ & $\begin{array}{l}0.236^{*} \\
(0.130)\end{array}$ & $\begin{array}{c}0.011 \\
(0.142)\end{array}$ & $\begin{array}{l}-0.122 \\
(0.173)\end{array}$ \\
\hline Percentage boys * Mathematics & $\begin{array}{c}0.651^{* * *} \\
(0.194)\end{array}$ & $\begin{array}{c}0.584^{* * *} \\
(0.187)\end{array}$ & $\begin{array}{c}0.529 * * \\
(0.218)\end{array}$ & $\begin{array}{c}0.564 * * * \\
(0.181)\end{array}$ & $\begin{array}{c}0.701^{* * *} \\
(0.215)\end{array}$ \\
\hline Percentage boys * Science & $\begin{array}{c}0.387 * * \\
(0.194)\end{array}$ & $\begin{array}{l}0.384^{*} \\
(0.223)\end{array}$ & $\begin{array}{c}0.222 \\
(0.174)\end{array}$ & $\begin{array}{c}0.302 \\
(0.185)\end{array}$ & $\begin{array}{l}0.437 * \\
(0.230)\end{array}$ \\
\hline $\begin{array}{l}\text { Observations } \\
\text { R-squared }\end{array}$ & $\begin{array}{c}238 \\
0.924\end{array}$ & $\begin{array}{c}238 \\
0.933\end{array}$ & $\begin{array}{c}238 \\
0.923\end{array}$ & $\begin{array}{c}238 \\
0.918\end{array}$ & $\begin{array}{c}238 \\
0.890\end{array}$ \\
\hline
\end{tabular}


Figure 1 . The cross country correlation between the share of immigrant pupils and the segregation index D.

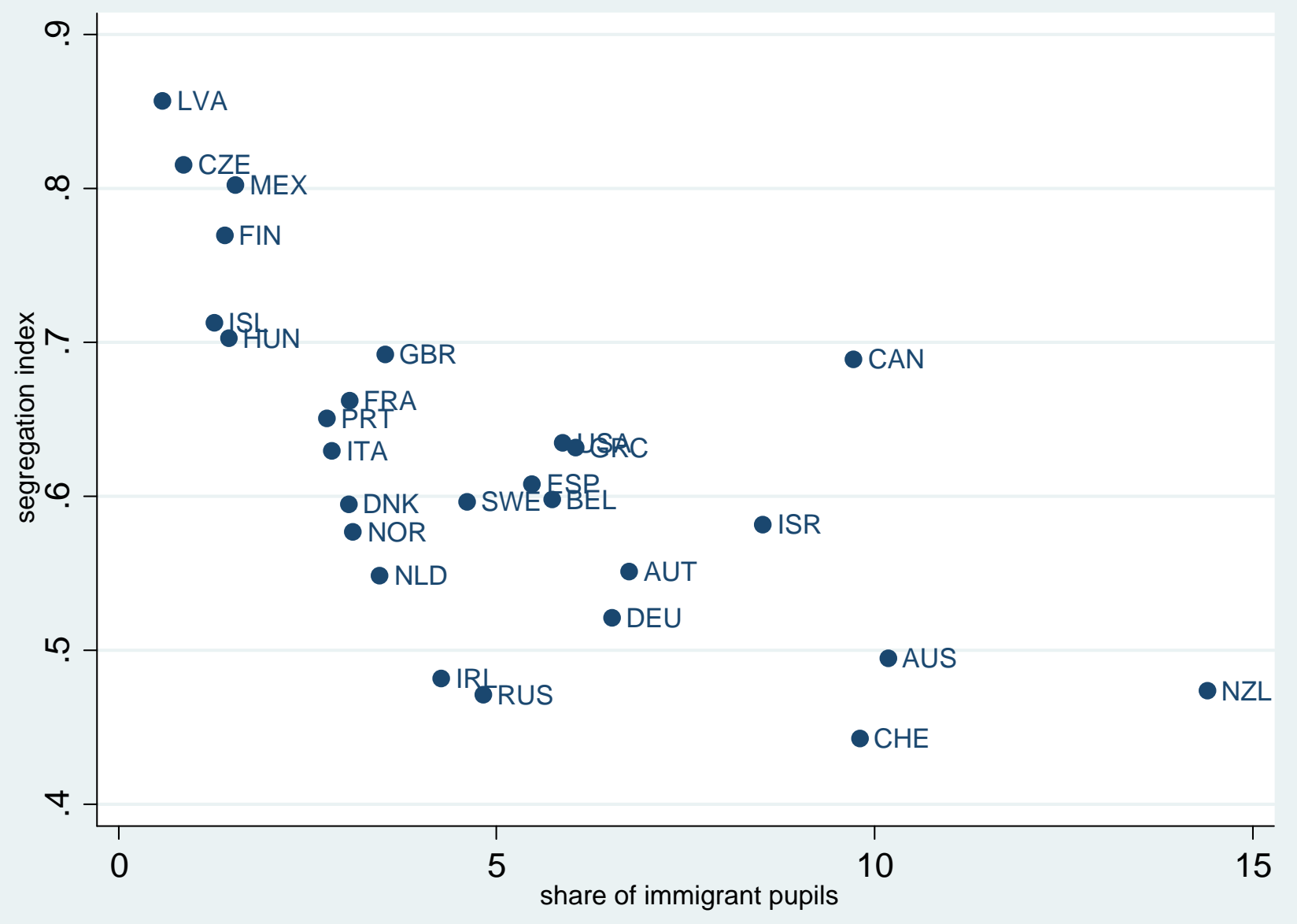

